\title{
Application of Accounting Information Systems for Individual Performance
}

\author{
Rahmawati, SE, M.Si, AK, CA, Hasbi Abbas \\ STIE Muhammadiyah Palopo, Indonesia \\ Rahmawati345@yahoo.co.id
}

\begin{abstract}
This study aims: To determine the effect of the application of accounting information system of individual performance in the regional work units. By testing the validity discriminate PLS associated with the principle that the gauges (manifest variables) distinct constructs should not be correlated with the height, the information technology that is implemented in the organization should be able to provide benefits to the individual and organizational performance and provide comfort for the wearer. Information technology can benefit the individual and organizational performance is an information technology that can be applied easily. The way to test the validity of discriminates with reflexive indicators by comparing the square root of AVE for each construct with the correlation between the constructs in the model. Good discriminate validity was shown on the square root of AVE for each construct is greater than the correlation between the constructs in the model Fornell and Larcker and results of SIA1 to SIA8 otherwise well. Limitations of research is conducted still $\mathrm{b} \mathrm{M}$ any factors in the implementation of other information systems that could affect the company's performance, but not used and researched in this study. Future studies are expected to incorporate these factors to be studied, for example, the level of consumer confidence, the level of competence, ease of use of information systems, the benefits of the system information.
\end{abstract}

Keywords: Accounting Information Systems, Competence, Tegnology, Leisure

\section{Introduction}

One result of the development of information technology is widely used by the organization to carry out its operational activities is the information system. Laudon and Laudon (2005) in Tri (2008) defines information systems as a set of components that are interconnected, which collect (or retrieve), process, store, and distribute information to support decision making and control in an organization. Along with advances in computer technology and information today, accounting information system has been developed into the accounting information system berbasisis computer. Computerized Accounting Information System enables financial statement users can see at any time the financial statements more quickly and accurately. Presentation of financial and non-financial can be done more easily with the support package of accounting information systems program which now a day's more and more variations and can be obtained easily in the market. Application of the Information Systems Unit (SKPD) Palopo will affect the performance of individuals, either directly or indirectly. Application of the Information Systems Unit (SKPD) Palopo can have a positive impact or a negative impact on Individual Performance in Work Units (SKPD) Palopo it. Performance is the result of employee performance both in quantity and quality (Tjokroaminoto, 2007 in Tri, 2008). Individual performance can be seen from the results of the individual work achieved in carrying out the task assigned to him on the basis of skills, experience, and skills that be used by individuals in completing a job. Related research on accounting information systems has been carried out and had mixed results as research conducted by Tri (2008), indicates that the application of accounting information system has a positive and significant impact on the performance of individuals in Malang City Government. This shows that the better the applicable accounting information systems within an organization, hence increasing the performance of individuals within the organization. And provision Amalia (2011) stated that Based on the regression data processed it can be seen that the users of accounting information systems (AIS user involvement, support of top management, and the formalization of development SIA) has a significant influence on the performance of the SIA. However, different results shown by Hand (2007) states that the interest in the use of SI (System Information) not significant effect on use information System. 


\section{Literature Review}

Theory of Reasoned Action (TRA) is a theory that is associated with the attitude and behavior of individuals in carrying out the activities. Someone will take advantage of SI on the grounds that such a system would produce benefits for themselves. Sheppard et al. (1988) in Hand (2007) states that the TRA was used to predict the behavior in many ways. TRA perform the phases of human behavior. In the early stages, the behavior (behavior) is assumed to be determined by the intention (intention). In the next phase, the intention can be described in terms of attitudes toward behavior (attitudes toward the behavior) and subjective norm (subjective norms) in the form of beliefs about the consequences of doing the behavior of expectations of the relevant normative. So overall a person's behavior can be explained by considering the trust, because trust someone to represent the information they have about themselves and the world around it (Jogiyanto, 2007 in Dwi-Iranto, 2012). The system is a group of elements that are closely related to each other that function together to achieve certain goals. Usually made to handle something repeatedly or regularly occur. System as an entity that contains parts - parts that affect each other, which is coordinated to achieve one or more general purpose. Brown, Dennis \& Venkatesh (2010), Brown, (2011) and Morris, Hall, Davis, Davis \& Walton (2003) in Wulandari (2006) states that the system is a group of components that are connected and work together to achieve goals to receive input and produce output in a process of organized information, accept that describes an event - real events and can be used as a tool for making a decision (Kusnandar, 2007). Accounting information system consists of five components, namely: People who operate the system and carry out a variety of functions, procedures, both manual and automated involved in collecting, processing and storing data on the activities of the organization Data about the organization's business processes, software used to process data organization, information technology infrastructure, including computers, peripherals (peripheral device) and equipment for network communication. According to Simamora (2004), performance assessment is the process used by the organization to evaluate the implementation of the work of individual employees. Andhika (2007) in Mangkunagara (2002) stated that "assessment of employees is a systematic evaluation of the work of employees and potential can be developed, the assessment is the process of assessment or determination of value, quality, or the status of some of the objects people or something ". Mangkuprawira (2002) and Wulandari (2006) mention some of the benefits of performance appraisal.

\section{Methodology}

Descriptive statistics provide a picture or description of a data seen from the average value (mean), median mode is standard deviation, variance, maximum, minimum, sum, range, kurtosis and skewness (skewed distribution), Ghozali (2006: 19), Analysis of Partial Least Square (PLS), methods of data analysis used in this study is Partial Least Square (PLS) .Partial Least Square (PLS) is a multivariate analysis technique that is used to project a linear relationship between the variables of observation (Hand et al., 2012). PLS goal is to test the theory of the weak and weak data, such as the sample size is small or there is a problem normality of the data, to predict the effect of exogenous variables on endogenous variables, Ghozali and southern (2014: 5). With the structural equation is as follows:

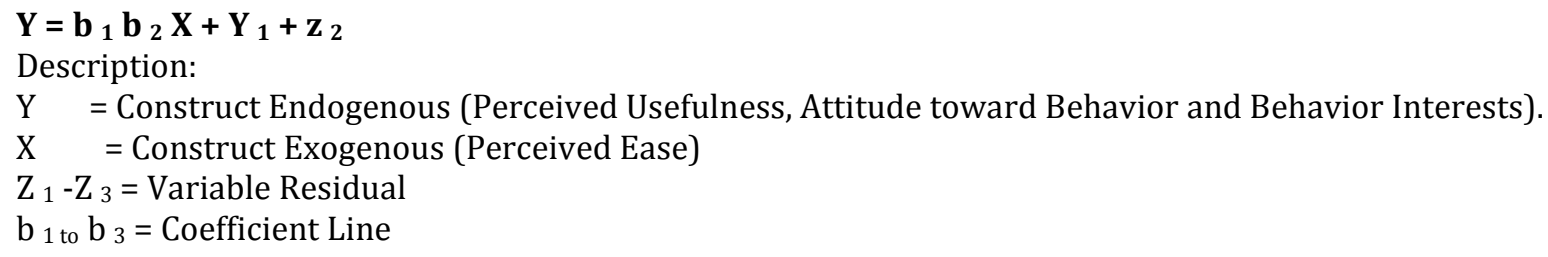

The steps that must be done in the PLS, Ghozali and Southern (2014: 74)

\section{Research Finding: Evaluation Model Measurements (Outer Model) to construct Reflexive}

Outer Model is a model that connects measurement indicators with latent variables. The model is used to determine the validity and reliability of linking indicators with latent variables. Indicators in this study were reflective as indicators of latent variables affecting the indicator. F or the use 3 way measurement according 
Ghozali and Southern (2014: 74), namely: Validities convergent relate to the principle that the gauges (manifest variables) of a construct supposed to be highly correlated. Test the validity of convergent indicators reflexive with WarpPLS 4.0 program can be seen from the loading factor values for each indicator constructs. Rule of thumb commonly used to assess the validity of convergent value loading factor should be more than 0.7 for studies that are confirmatory and loading factor value between from 0.6 to 0.7 for exploratory research that is still acceptable and the value of average variance extracted (AVE) must be greater than 0.5. However, to study the early stages of development scale of measurement, the value of loading factor of 0.5 to 0.6 is considered quite Chin (1998) in Ghozali and Southern (2014: 74). The convergent validity of the test results as follows: Convergent validity of the test results with the parameter value of loading factor that the value of loading factor for each - each indicator has a value above (> 0.50) except for a few indicators that still has a value below 0.50. To construct Accounting Information Systems consisting of eight indicators that SIA1 $=0.947$, sia2 $=0.947$, SIA3 $=0.595$, SIA4 $=0.947$, SIA5 $=$ 0.595 , SIA6 $=0589$, SIA7 $=0.595$, SIA8 $=0.947$, which of the eight indicators are no indicators that have a value below 0.50 so this indicator is not there in the droop of the model. Then to construct Individual Performance consisting of eight indicators that $\mathrm{KI} 1=0931, \mathrm{ki} 2=0892, \mathrm{KI} 3=0.456, \mathrm{KI} 4=0.456, \mathrm{KI} 5=0931$, KI6 $=0.474, \mathrm{KI} 7=0.456, \mathrm{KI} 8=0931$, which of the eight indicators that there are four indicators that still has a value below 0.50 which is an indicator $\mathrm{KI} 3=0.456, \mathrm{KI} 4=0.456, \mathrm{KI} 6=0.474, \mathrm{KI} 7=0.456$, so this indicator in the droop of the model. After testing a second phase in which all indicators of the construct in the droop of the model, then obtained a new loading factor values are presented in Table 4.10. Construct that is already above 0.50. It can be concluded that the indicator forming construct Accounting Information Systems, Individual Performance, Average Variance Extracted (AVE) for each - each construct is in Accounting Information Systems $=0624$; Individual Performance $=0.930$, already has a value above 0.50 , meaning that both constructs are categorized valid. Thus for convergent validity test consisting of cross loading the parameter value and Average Variance Extracted (AVE) terkategori valid. Further validity discriminant relate to the principle that the gauge - measuring (manifest variables) distinct constructs should not be correlated with height. How to test the validity of discriminant with reflexive indicators by comparing the square root of AVE for each construct with the correlation between the constructs in the model. The validity of the discriminant which is well demonstrated on the square root of AVE for each construct is greater than the correlation between the constructs in the model Fornell and Larcker (1981) in Ghozali and Southern (2014: 74). From the table 4:12 above can be seen that the value of the square root of the AVE to each construct is greater than the value of the correlation between the constructs in the model that each - each worth Accounting Information Systems $=0.790$; Individual Performance $=0.964$. To measure the reliability of a construct and refeksif indicator can be done in two ways, namely by Cronbach's Alpha and Composite Reliability. Rule of Thumb are typically used to assess reliability Composite Reliability construct a value must be greater than 0.7 for studies that are confirmatory and the value 0,6 to 0.7 is acceptable for research that is exploratory, however to study the early stages of development scale of measurement, the value of loading factor of 0.5 to 0.6 is considered quite Chin (1998) in Ghozali and Southern (2014: 74) In PLS-SEM using the program WarpPLS 4.0 is more advisable to use a composite reliability. Accounting Information Systems = 0.927; Individual Performance $=0,981$, already has a value above from 0.50, meaning that the construct four categorized reliable. Thus, to test convergent validity with the parameter value of loading factor and Average Variance Extracted (AVE), discriminant validity test parameters AVE square roots and Correlation between latent constructs and reliability tests with the parameters Composite Reliability valid and reliable. In assessing the structural or inner model of the model with 4.0 WarpPLS can to see Rule of Thumb The structural model test results or inner structural model of the model in this study can be presented in the following figure:

\section{Figure 1: Results Analysis of Structural Model (Inner Model)}

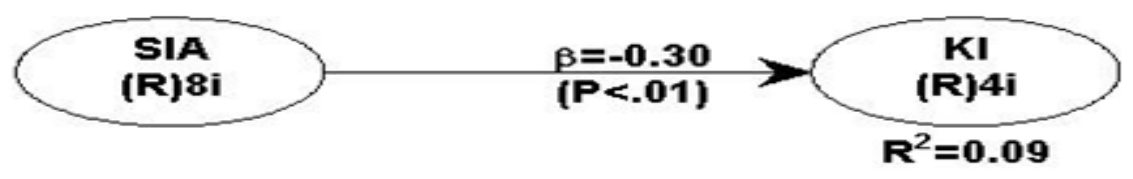

Sumber: Lampiran 4b 2015 
From the output of general result of the above can be seen the model has the fit is good, where the value of the $\mathrm{P}$ value for the Average Path Coefficient (APC), Average R-squared (ARS) and the Average Adjusted $R$ Square (Aars) $<1$ with the value of each ie APC $=0.297$, ARS $=0.088$, Aars $=0.076$. Then the VIF block Average value (AVIF) and Average Full collinearity VIF (AFFIV), which is produced is $<3.3$, which means that no matter multicoloniarity between indicators and between latent variables and values AFVIF = 1.096. Furthermore, the resulting value GoF is $0.261>0.25$, which means a good fit model. For index Symson's paradox (SPR), the R-squared contribution ratio (RSCR), and the Statistical Suppression Ratio (SSR), each producing the same value is 1 , which means there is no problem of causality in the model. Then for Nonlinear Bivariate Causality Direction Ratio (NLBCDR) each - each produces the same value is 1 , which means there is no problem of causality in the model. $1 \%$ probability level indicates the line is already significant. The interpretation explained namely Accounting Information Systems has a direct influence positively and significantly to the Individual Performance with $P=0.001(<0.05)$, this coefficient indicates that with the increase in Accounting Information Systems will be followed by improvement of individual performance significantly. To determine the proportion of variance of certain exogenous variables on endogenous variables, can be calculated by using a partial F-test (effect size) in Ghozali and southern (2014: 98). The value of the resulting effect size is: effect size generated to construct Accounting Information Systems to construct individual performance is of $0.088>0.02$ is included in the small category. Based on the table above 4:18 obtained Adjusted R-Squared value to construct individual performance that is equal to 0.076 which means that the effect of the construct of Accounting Information Systems in explaining construct individual performance is $7.6 \%$ and the remaining $92.4 \%$ influenced by other constructs beyond this research model.

\section{Conclusion}

From results it concludes that the use of information systems greatly helps to increase the performance of individual employees. Construct individual performance that is equal to 0.076 which means that the effect of the construct of Accounting Information Systems in explaining constructs Individual Performance, Future studies are expected to not restrict sampling areas on just one area only, so as to represent the wider population. In addition, the sample should not be confined to the public sector organizations alone, but expanded so as to include organizations in other sectors.

\section{References}

Amalia, R. (2011). User Effect of Accounting Information Systems Managerial Performance Improvement in Corporate Banking in Makassar. Essay: Hasanuddin University in Makassar.

Andhika, W. (2007). Influence of Employee Perceptions of Computer-Based Information System Implementation of the Performance. Essay. Malang: UB.

Brown, S. A. (2011). Expectation Confirmation in Technology Use, (2002), 1-14. http://doi.org/10.1287/isre.1110.0357

Brown, S. A., Dennis, A. R. \& Venkatesh, V. (2010). Predicting Collaboration Technology Use. Integrating Technology Adoption and Collaboration Research, 27 (2), 9-53. http://doi.org/10.2753/MIS07421222270201

Djatikusumo, D. S. (2005). Role of Management Information Systems and Information Technology in Supporting Agricultural Products Marketing and Agribusiness. Journal of Economics and Management, 6(2). Master of Management Graduate Program Gajayana University. Poor. http: // Informatika.com/Perkembangan Research Center for Information Technology in Indonesia. Accessed on 1 April 2015.

Dwi, I. B. (2012). Effect of User Satisfaction Individual Performance Against Information Systems (Studies in PT. PLN (Persero) Distribution Central Java and Yogyakarta). Essay. Faculty of Economics and Business, University of Diponegoro.

Ghozali, I. \& Southern, H. (2014). Partial Least Square: Concepts Techniques and Applications Using Smart Program PLS 3.0 for Empirical Research. Diponegoro University of Semarang.

Ghozali, I. (2006). Applications Multivariate Analysis with SPSS Program. Diponegoro University of Semarang.

Hand, N. U., Santoso, H. \& Primary, A. I. (2012). Factors Affecting Competitiveness Improvement Cluster Furniture Jepara. Journal of Industrial Engineering, 13(1), 25 
Hand, R. (2007). Analysis of Factors Affecting Interest Utilization Information System and System Usage. essay. STIE Atma Bhakti Surakarta.

Kusnandar, N. (2007). Information Technology. http: // Student Association Library and Information Science UWKS / Information Technology. Accessed on 1 April 2015.

Mangkunagara, A. P. (2002). Resource Management Company. Rosda. Bandung.

Morris, M. G., Hall, M., Davis, G. B., Davis, F. D. \& Walton, S. M. (2003). User Acceptance of Information Technology. Toward Aunified View, 1, 27(3), 425-478.

Simamora, H. (2004). Human Resource Management, Third Edition, First Printing, Publishing Section STIE YKPN, Yogyakarta.

Tri, A. M. (2008). Effect of Application of Accounting Information Systems Performance against Individuals (Research on Environmental sectors in the City Government of Malang). Essay. Faculty of Economics, University of Brawijaya.

Wijayanti, T. (2013). Effect of Accounting Information Systems Technology, Trust Accounting Information Systems Technology, and User Satisfaction against Individual Performance (Studies in the Department of Revenue of Regional Finance and Asset Management Area (DPPKAD) Grobogan). Essay. Faculty of Economics and Business, University of Muhammadiyah Surakarta

Wulandari, S. (2006). Effect of Computer-Based Information System and Confidence in the Individual Performance. Essay. Brawijaya University. Poor.

Wuryaningrum, A. (2007). Effect of Information Technology on individual performance with confidence and Complexity System as Moderating Variable. Essay. Brawijaya University. Poor.

www.google,http://www.seputarpengetahuan.com/2015/03/9-pengertian-sistem-ssinformasimenurut.html. Accessed on 1 April 2015. 